\title{
Badan Layanan Umum \\ Sebuah Pola Baru Dalam Pengelolaan Keuangan Di Satuan Kerja Pemerintah
}

Oleh : Indarto Waluyo

\begin{abstract}
Abstrak
Dalam dekade terakhir reformasi keuangan negara telah memasuki babak baru, salah satu agendanya adalah adanya pergeseran dari pengganggaran tradisional menjadi pengganggaran berbasis kinerja. Dengan berbasis kinerja ini, arah anggaran (penggunaan dana pemerintah) tidak lagi berorientasi pada input, tetapi lebih pada output. Perubahan ini merupakan momentum yang penting dalam rangka proses pembelajaran untuk menggunakan sumber daya pemerintah yang lebih efektif, efisien dan produktif, tetapi tetap dapat memenuhi kebutuhan dana yang makin tinggi seiring dengan keterbatasan sumber dana yang ada. Penganggaran yang berorientasi pada output merupakan praktik yang telah dianut luas oleh pemerintahan modern di berbagai belahan negara Eropa dan Amerika. Pendekatan penganggaran yang demikian sangat diperlukan bagi satuan kerja instansi pemerintah (satker yang memberikan pelayanan kepada publik. Salah satu alternatif untuk mendorong peningkatan pelayanan publik adalah dengan mewiraswastakan pemerintah. Mewiraswastakan pemerintah (enterprising the government) adalah paradigma yang memberi arah yang tepat bagi pengelolaan keuangan sektor publik, seperti yang diamanatkan dalam undang-undang nomer 17 Tahun 2003 tentang Keuangan Negara.

Dengan dikeluarkannya undang-undang nomer 1 tahun 2004 tentang Perbendaharaan Negara membuka celah baru bagi penerapan anggaran berbasis kinerja di lingkungan instansi pemerintah. Dalam undang-undang tersebut, instansi pemerintah yang tugas pokok dan fungsinya (tupoksi) memberikan pelayanan kepada masyarakat dapat menerapkan pengelolaan keuangan yang fleksibel dengan menonjolkan produktivitas, efisiensi, dan efektivitas.Satuan kerja baru tersebut bernama Badan Layanan Umum (BLU).

Untuk dapat menjadi Badan Layanan Umum, suatu instansi pemerintah harus memenuhi tiga persyaratan pokok, yaitu persyaratan substantif, yang terkait dengan penyelanggaraan layanan umum, persyaratan teknis yang terkait dengan kinerja pelayanan dan kinerja keuangan, serta persyaratan administratif terkait dengan terpenuhinya dokumen seperti pola tata kelola, rencana strategis bisnis, standar layanan minimal, laporan keuangan pokok, dan laporan audit / bersedia untuk diaudit.
\end{abstract}

Kata kunci : Badan Layanan Umum, Pola Baru Pengelolaan Keuangan Instansi Pemerintah.

\section{LATAR BELAKANG MASALAH}

Dalam dua dasa warsa terakhir, reformasi administrasi publik makin menguat di berbagai belahan dunia. Gelombang New Public Management (NPM) yang didasarkan atas pengalaman beberapa negara di Eropa, Amerika Serikat, dan negara maju lainnya secara bertahap diadopsi ke dalam tata kelola pemerintahan di berbagai negara, termasuk Indonesia. Transformasi manajemen pemerintahan dalam New Public Management mulai dari penataan

${ }^{1}$ Dosen Jurusan Pendidikan Akuntansi - Universitas Negeri Yogyakarta 
kelembagaan, reformasi kepegawaian, dan reformasi pengelolaan keuangan Negara (Mahmudi, 2003, dalam Meidyawati).

Di dalam NPM tersebut pemerintah dianjurkan untuk meninggalkan paradigma lama seperti administrasi tradisional yang cenderung lebih mengedepankan sistem dan prosedur, birokratis yang gemuk dan tidak efisien, pemberian layanan yang lambat serta tidak efektif, digantikan dengan paradigma baru yang berorientasi pada kinerja dan hasil. Pemerintah dianjurkan untuk melepaskan diri dari birokrasi klasik, dengan mendorong organisasi dan pegawai agar lebih fleksibel, dan menetapkan tujuan, serta target organisasi secara lebih jelas sehingga memungkinkan pengukuran hasil (D.Moynihan, Sanjai K Pandey, 2003, dalam Meidyawati).

Paradigma baru pengelolaan keuangan negara sesuai dengan paket peraturan perundang-undangan di bidang keuangan negara meliputi 1) Undang-undang No. 17 Tahun 2003 tentang Keuangan Negara, 2) Undang-Undang Nomor 1 Tahun 2004 Tentang Perbendaharaan Negara, 3) UU Pemeriksaan Pengelolaan dan Tanggungjawab Keuangan Negara setidaknya mengandung tiga kaidah manajemen keuangan Negara, yaitu: orientasi pada hasil, profesionalitas, akuntabilitas dan transparansi. Paradigma ini dimaksudkan untuk memangkas ketidakefisienan, dan meningkatkan produktivitas.

Masalah klasik dalam bidang pelayanan umum adalah kualitas dan harga, bila dibandingkan dengan sektor privat, sektor publik masih sering tertinggal mengenai kualitas pelayanan, hal ini sering dikaitkan dengan harga yang lebih murah yang harus dibayar oleh para pengguna. Tabel 1 menggambarkan perbandingan tersebut :

Tabel 1. Perbandingan Kualitas serta Harga Layanan Sektor Privat dan Publik

\begin{tabular}{|l|l|l|l|l||}
\hline No & Item & Privat & Publik & Ideal \\
\hline 1 & Kualitas & Tinggi & Rendah & Tinggi \\
\hline 2 & Harga & Tinggi & Rendah & Sharing \\
\hline 3 & Lembaga & Swasta & Pemerintah & Pemerintah \\
\hline 4 & Pengelolaan & Korporasi & Govermental & Korporasi \\
\hline
\end{tabular}

Berdasarkan paket perundangan tersebut di atas, instansi pemerintah yang tugas pokok dan fungsinya memberikan pelayanan kepada masyarakat dapat menerapkan pola pengelolaan keuangan yang fleksibel, berupa keleluasaan untuk menerapkan praktek-praktek bisnis yang sehat dalam rangka memaksimalkan pelayanan kepada masyarakat dengan tetap menonjolkan produktivitas, efisiensi, dan efektifitas dapat dilaksnakan melalui pola pengelolaan keuangan baru yang bernama Badan Layanan Umum. Badan Layanan Umum pada dasarnya adalah alat untuk meningkatkan kinerja pelayanan publik melalui penerapan manajemen keuangan yang berbasis pada hasil,profesionalitas, akuntabilitas dan transparansi.

\section{MENGAPA BADAN LAYANAN UMUM?}

Di lingkungan birokrasi pemerintahan, terdapat banyak satuan kerja yang berpotensi untuk dikelola secara lebih efisien dan efektif melalui pola BLU. Ada yang mendapatkan imbalan dari masyarakat dalam proporsi yang signifikan terkait dengan pelayanan yang diberikan, dan ada pula yang bergantung sebagian besar pada dana APBN/APBD. Satuan kerja yang memperoleh pendapatan dari layanannya dalam porsi signifikan, dapat diberikan keleluasaan dalam mengelola sumber daya untuk meningkatkan pelayanan yang diberikan. Peluang ini secara khusus disediakan bagi satuan kerja pemerintah yang melaksanakan tugas operasional pelayanan publik. Hal ini merupakan upaya peng-agenan aktivitas yang tidak harus dilakukan oleh lembaga birokrasi murni, tetapi oleh instansi pemerintah dengan pengelolaan ala bisnis, sehingga pemberian layanan kepada masyarakat menjadi lebih efisien dan efektif. 
Jargon yang dikembangkan dalam BLU adalah "Let the managers manage, make the managers manage. Jargon pertama mengandung makna memberi kesempatan kepada manager (pimpinan satuan kerja) mengelola jasa-jasa pemerintah (pendidikan, rumah sakit, dsb) dan menggunakan anggaran dengan cara yang paling efisien dan efektif, sedangkan jargon kedua bermakna memastikan bahwa pinpina satker tersebut telah melakukan pengelolaan dengan efisien dan efektif sehingga menghasilkan kinerja. BLU merupakan implementasi dari enterprising government dan pengangaran berbasis kinerja.

Agar dapat menjalankan fungsi dan tugas secara optimal, maka BLU memiliki fleksibilitas dalam pengelolaannya. Fleksibilitas yang dimiliki tersebut antara lain :

1. Pendapatan dan belanja

Pendapatan operasional BLU yang berasal dari PNBP (Penerimaan Negara Bukan Pajak) dapat digunakan langsung tanpa terlebih dahulu disetorkan ke rekening kas negara, ini dimungkinkan karena BLU menggunakan mekanisme Rencana Bisnis dan Anggaran (RBA). Pertanggungjawabannnya akan dilaporkan dalam Laporan Realisasi Anggaran melalui SPM/SP2D pengesahan. Anggaran belanja BLU merupakan anggaran fleksibel berdasarkan kesetaraan antara volume kegiatan pelayanan dengan jumlah pengeluaran, belanja dapat bertambah/berkurang dari yang dianggarkan sepanjang pendapatan terkait bertambah atau berkurang, setidaknya proporsional.

2. Pengelolaan kas

Dalam rangka pengelolaan kas yang optimal, BLU merencanakan cash flows kasnya, baik cash inflows maupun cash outflows, termasuk mendapatkan sumber dana untuk menutup defisit jangka pendek, maupun mendapatkan dana untuk investasi jangka panjang, serta memanfaatkan kas yang menganggur (idle cash) untuk memperoleh pendapatan tambahan, seperti deposito berjangka pendek, dsb.

3. Pengelolaan piutang dan utang

BLU dapat mengelola piutang (memberi pinjaman kepada pihak lain) maupun utang (meminjam dana dari pihak lain) sepanjang dikelola dan diselesaikan secara tertib, efisien, ekonomis, transparan, dan bertanggungjawab serta memberikan nilai tambah sesuai praktik bisnis yang sehat.

4. Investasi

BLU dapat melakukan investasi jangka pendek maupun jangka panjang, sepanjang dikelola dan diselesaikan secara tertib, efisien, ekonomis, transparan, dan bertanggungjawab serta memberikan nilai tambah sesuai praktik bisnis yang sehat..

5. Pengadaan Barang dan Jasa

Pengadaan barang dan jasa BLU yang sumber dananya berasal dari pendapatan negara bukan pajak (PNBP), hibah tidak terikat, dan hasil kerjasama dengan pihak lainnya, dapat dilaksanakan berdasarkan ketentuan pengadaan barang/jasa yang ditetapkan pimpinan BLU, sepanjang tidak betentangan dengan peraturan yang berlaku.

6. Akuntansi

BLU dapat mengembangkan kebijakan, sistem, dan prosedur pengelolaan keuangan sendiri, sepanjang tidak bertentangan dengan Standar Akuntansi Keuangan (SAK) dan Standar Akuntansi Pemerintah (SAP).

7. Remunerasi

Pejabat pengelola, dewan pengawas dan pegawai dapat diberikan remunerasi berdasarkan tingkat tanggungjawab dan tuntutan profesionalisme yang diperlukan, dengan mempertimbangkan kemampuan keuangan satker yang ada.

8. Surplus/defisit

Surplus anggaran BLU dapat digunakan dalam tahun anggaran berikutnya kecuali atas perintah Menteri Keuangan/gubernur/bupati/walikota, sesuai dengan kewenangannya, 
disetorkan sebagian atau seluruhnya ke Kas Umum Negara/Daerah dengan mempertimbangkan posisi likuiditas BLU

9. Status kepegawaian (PNS dan Non PNS)

BLU dalam kegiatannya memberikan layanan jasa, dapat memperkerjakan tenaga profesional non PNS. Sehingga dalam BLU dikenal adanya pegawai PNS dan pegawai non PNS. Adapun honorarium pegawai non PNS tersebut tergantung dari kemampuan keuangan masing-masing BLU, dengan tetap mempertimbangkan peraturan yang berlaku.

Dari gambaran di atas terlihat bahwa pola pengelolaan keuangan pada BLU merupakan pola pengelolaan keuangan yang merupakan pengecualian dari ketentuan pengelolaan keuangan satuan kerja pemerintah pada umumnya. BLU diberikan fleksibilitas berupa keleluasaan untuk menerapkan praktik-praktik bisnis yang sehat (berdasarkan kaidah-kaidah manajemen yang baik dalam rangka pemberian layanan yang bermutu dan berkesinambungan) untuk meningkatkan pelayanan kepada masyarakat dalam rangka memajukan kesejahteraan umum dan mencerdaskan kehidupan bangsa.

\section{BADAN LAYANAN UMUM \\ Karakteristik Badan Layanan Umum (BLU)}

Dalam upaya meningkatkan layanan kepada publik, maka diperlukan pengaturan yang spesifik mengenai satuan kerja pemerintahan yang melakukan pelayanan kepada masyarakat yang saat ini bentuknya beraneka macam. Sesuai dengan pasal 1 butir (1). Undang-undang Nomor 23 Tahun 2005 tentang Pengelolaan Keuangan Badan Layanan Umum dinyatakan bahwa : "Badan Layanan Umum adalah instansi di lingkungan Pemerintah yang dibentuk untuk memberikan pelayanan kepada masyarakat berupa penyediaan barang dan/atau jasa yang dijual tanpa mengutamakan mencari keuntungan dan dalam melakukan kegiatannya didasarkan pada prinsip efisiensi dan produktivitas. Selanjutnya dalam ayat 2 dinyatakan, "Pola Pengelolaan Keuangan Badan Layanan Umum, yang selanjutnya disebut PPK-BLU, adalah pola pengelolaan keuangan yang memberikan fleksibilitas berupa keleluasaan untuk menerapkan praktek-praktek bisnis yang sehat untuk meningkatkan pelayanan kepada masyarakat dalam rangka memajukan kesejahteraan umum dan mencerdaskan kehidupan bangsa, sebagaimana diatur dalam Peraturan Pemerintah ini, sebagai pengecualian dari ketentuan pengelolaan keuangan negara pada umumnya.

Berdasar penjelasan undang-undang di atas, karakteristik satuan kerja pemerintahan / entitas yang merupakan Badan Layanan Umum, adalah sebagai berikut:

1. Merupakan satuan kerja pemerintahan yang pengelolaannya tidak dipisahkan dari kekayaan Negara;

2. Entitas tersebut menghasilkan barang dan/atau jasa yang diperlukan masyarakat;

3. Tidak berorientasi mencarai keuntungan (nirlaba)

4. Diberi fleksibilitas dalam pengelolaan keuangan dengan prinsip efisiensi dan produktivitas seperti perusahaan swasta, untuk meningkatkan pelayanan kepada masyarakat dalam rangka memajukan kesejahteraan umum dan mencerdaskan kehidupan bangsa.

5. Rencana kerja, anggaran dan pertanggungjawabannya dikonsolidasikan dengan entitas vertikal di atasnya (kementrian / lembaga) sebagai instansi induk

6. Penerimaan negara bukan pajak (PNBP) baik pendapatan maupun sumbangan / hibah dapat digunakan secara langsung;

7. Pegawai Badan Layanan Umum dapat terdiri dari pegawai negeri sipil dan bukan pegawai negeri sipil / pegawai BLU

8. Walaupun dikelola secara koorporasi, BLU bukan merupakan subyek pajak. 


\section{Persyaratan}

Suatu entitas pemerintah yang ingin mengajukan menjadi BLU harus memenuhi 3 persyaratan, yakni : persyaratan Substantif, persyaratan Teknis, dan persyaratan Administratif. (www.perbendaharaan.go.id)

\section{Persyaratan Substantif}

Persyaratan substantif adalah persyaratan dasar yang merupakan syarat awal suatu entitas bisa menjadi BLU, persyaratan ini meliputi :

1. Menyelenggarakan tugas pokok dan fungsi yang berhubungan dengan:

a. Penyediaan barang atau jasa layanan umum, seperti pelayanan di bidang kesehatan, penyelenggaraan pendidikan, serta pelayanan jasa penelitian dan pengembangan (litbang);

b. Pengelolaan wilayah/kawasan tertentu untuk tujuan meningkatkan perekonomian masyarakat atau layanan umum seperti otorita dan Kawasan Pengembangan Ekonomi Terpadu (Kapet); atau

c. Pengelolaan dana khusus dalam rangka meningkatkan ekonomi atau pelayanan kepada masyarakat, seperti pengelola dana bergulir untuk usaha kecil dan menengah.

2. Bidang layanan umum yang diselenggarakan bersifat operasional yang menghasilkan semi barang/jasa publik (quasi public goods)

3. Dalam kegiatannya tidak mengutamakan keuntungan.

\section{Persyaratan Teknis}

Persyaratan teknis adalah persyaratan kinerja yang harus dipenuhi. Persyaratan Teknis meliputi kinerja pelayanan dan kinerja keuangan:

1. Kinerja pelayanan di bidang tugas pokok dan fungsinya layak dikelola dan ditingkatkan pencapaiannya melalui BLU sebagaimana direkomendasikan oleh menteri/pimpinan lembaga /kepala SKPD sesuai dengan kewenangannya; dan

2. Kinerja keuangan satker instansi yang bersangkutan sehat sebagaimana ditunjukan dalam dokumen usulan penetapan BLU.

\section{Persyaratan Administratif}

Persyaratan administratif adalah persyaratan yang harus terpenuhi dalam rangka kegiatan operasional BLU. Persyaratan administarif meliputi :

1. Pernyataan kesanggupan untuk meningkatkan kinerja pelayanan, keuangan, dan manfaat bagi masyarakat.Pernyataan tersebut disusun sesuai dengan format yang tercantum dalam lampiran Peraturan Menteri Keuangan Nomor 119/PMK.05/2007 dan bermaterai, ditandatangani oleh pimpinan satker Instansi Pemerintah yang mengajukan usulan untuk menerapkan PPK-BLU dan disetujui oleh menteri/pimpinan lembaga terkait.

2. Pola tata kelola. Merupakan peraturan internal satuan kerja Instansi Pemerintah yang menetapkan:

a. organisasi dan tata laksana, yang memuat antara lain struktur organisasi, prosedur kerja, pengelompokan fungsi yang logis, ketersediaan dan pengembangan sumber daya manusia;

b. akuntabilitas, yaitu mempertanggungjawabkan pengelolaan sumber daya serta pelaksanaan kebijakan yang dipercayakan kepada satuan kerja Instansi 
Pemerintah bersangkutan dalam mencapai tujuan yang telah ditetapkan secara periodik, meliputi akuntabilitas program, kegiatan, dan keuangan;

c. transparansi, yaitu adanya kejelasan tugas dan kewenangan, dan ketersediaan informasi kepada publik.

3. Rencana strategis bisnis, mencakup:

a. visi, yaitu suatu gambaran yang menantang tentang keadaan masa depan yang berisikan cita dan citra yang ingin diwujudkan;

b. misi, yaitu sesuatu yang harus diemban atau dilaksanakan sesuai visi yang ditetapkan, agar tujuan organisasi dapat terlaksana dan berhasil dengan baik;

c. program strategis, yaitu program yang berisi proses kegiatan yang berorientasi pada hasil yang ingin dicapai selama kurun waktu 1 (satu) sampai dengan 5 (lima) tahun dengan memperhitungkan potensi, peluang, dan kendala yang ada atau mungkin timbul; dan

d. kesesuaian visi, misi, program, kegiatan, dan pengukuran pencapaian kinerja;

e. indikator kinerja lima tahunan berupa indikator pelayanan, keuangan, administrasi, dan SDM;

f. pengukuran pencapaian kinerja, yaitu pengukuran yang dilakukan dengan menggambarkan apakah hasil kegiatan tahun berjalan dapat tercapai dengan disertai analisis atas faktor-faktor internal dan eksternal yang mempengaruhi tercapainya kinerja tahun berjalan.

4. Laporan keuangan pokok, terdiri atas:

a. Kelengkapan laporan:

- Laporan Realisasi Anggaran/Laporan Operasional Keuangan, yaitu laporan yang menyajikan ikhtisar sumber, alokasi, dan pemakaian sumber daya ekonomi yang dikelola, serta menggambarkan perbandingan antara anggaran dan realisasinya dalam suatu periode pelaporan yang terdiri atas unsur pendapatan dan belanja;

- Neraca/Prognosa Neraca, yaitu dokumen yang menggambarkan posisi keuangan mengenai aset, kewajiban, dan ekuitas pada tanggal tertentu;

- Laporan Arus Kas, yaitu dokumen yang menyajikan informasi kas sehubungan dengan aktivitas operasional, investasi, dan transaksi nonanggaran yang menggambarkan saldo awal, penerimaan, pengeluaran, dan saldo akhir kas selama periode tertentu;

- Catatan atas Laporan Keuangan, yaitu dokumen yang berisi penjelasan naratif atau rincian dari angka yang tertera dalam Laporan Realisasi Anggaran, Neraca/Prognosa Neraca, dan Laporan Arus Kas, disertai laporan mengenai kinerja keuangan.

b. Kesesuaian dengan standar akuntansi;

c. Hubungan antarlaporan keuangan.

d. Kesesuaian antara keuangan dan indikator kinerja yang ada di rencana strategis;

e. Analisis laporan keuangan.

5. Standar Pelayanan Minimum (SPM) merupakan ukuran pelayanan yang harus dipenuhi oleh satuan kerja instansi pemerintah untuk menerapkan PK BLU. SPM ditetapkan oleh Menteri/Pimpinan Lembaga dalam rangka penyelenggaraan kegiatan pelayanan kepada masyarakat yang harus mempertimbangkan kualitas layanan, pemerataan, dan kesetaraan layanan biaya serta kemudahan memperoleh layanan.

SPM sekurang-kurangnya mengandung unsur: 
a. Jenis kegiatan atau pelayanan yang diberikan oleh satker. Jenis kegiatan merupakan pelayanan yang diberikan oleh satker baik pelayanan ke dalam (satker itu sendiri) maupun pelayanan yang diberikan kepada masyarakat. Jenis kegiatan ini merupakan tugas dan fungsi dari satker yang bersangkutan.

b. Rencana Pencapaian SPM. Satuan kerja menyusun rencana pencapaian SPM yang memuat target tahunan pencapaian SPM dengan mengacu pada batas waktu pencapaian SPM sesuai dengan peraturan yang ada.

c. Indikator pelayanan. SPM menetapkan jenis pelayanan dasar, indikator SPM dan batas waktu pencapaian SPM.

d. Adanya tanda tangan pimpinan satuan kerja yang bersangkutan dan menteri/pimpinan lembaga.

6. Laporan audit terakhir, merupakan laporan auditor tahun terakhir sebelum satuan kerja instansi pemerintah yang bersangkutan diusulkan untuk menerapkan PK BLU. Dalam hal satuan kerja instansi pemerintah tersebut belum pernah diaudit, satuan kerja instansi pemerintah dimaksud harus membuat pernyataan bersedia untuk diaudit secara independen yang disusun dengan mengacu pada formulir yang telah ditetapkan.

\section{Tata Kelola} pengawas

Dalam ruang lingkup tata kelola ini meliputi kelembagaan, kepegawaian, dan dewan

\section{Kelembagaan}

Pengelolaan Keuangan BLU dapat diterapkan oleh setiap instansi pemerintah yang secara fungsional menyelenggarakan kegiatan yang bersifat operasional. Instansi dimaksud dapat berasal dari dan berkedudukan pada berbagai jenjang eselon atau non eselon pada kementerian/lembaga. Sehubungan dengan itu, apabila instansi pemerintah yang menerapkan PK-BLU memerlukan perubahan status ataupun struktur kelembagaan, maka perubahan tersebut berpedoman pada ketentuan yang ditetapkan oleh Menteri Pendayagunaan Aparatur Negara.

\section{Kepegawaian}

Pejabat pengelola dan pegawai BLU dapat terdiri dari pegawai negeri sipil (PNS) dan/atau tenaga profesional non-PNS sesuai dengan kebutuhan BLU. Syarat pengangkatan dan pemberhentian pejabat pengelola dan pegawai BLU yang berasal dari PNS dilaksanakan sesuai dengan ketentuan peraturan perundang-undangan bagi PNS. Pejabat pengelola dan pegawai BLU yang berasal dari tenaga profesional non-PNS dapat dipekerjakan secara tetap atau berdasarkan kontrak.

\section{Dewan Pengawas}

Dewan Pengawas untuk BLU di lingkungan pemerintah pusat dibentuk dengan keputusan menteri/pimpinan lembaga atas persetujuan Menteri Keuangan.

Anggota dewan pengawas terdiri dari unsur-unsur pejabat dari kementerian negara/lembaga teknis yang bersangkutan, Kementerian Keuangan, dan tenaga ahli yang sesuai dengan kegiatan BLU.

\section{Perencanaan dan Penganggaran}


Perencanaan dan penganggaran meliputi rencana strategis bisnis dan pengintegrasiannya dalam RKA-K/L

\section{Rencana Strategis Bisnis dan Anggaran}

BLU menyusun rencana strategis bisnis lima tahunan dengan mengacu kepada Rencana Strategis Kementerian/Lembaga (Renstra K/L). Rencana strategis bisnis merupakan istilah yang pengertiannya sama dengan Renstra bagi instansi pemerintah. Oleh karena itu penyusunan rencana strategis bisnis berpedoman pada Instruksi Presiden Nomor 7 Tahun 1999 tentang Akuntabilitas Kinerja Instansi Pemerintah.

Sesuai dengan Inpres tersebut, rencana strategis mengandung visi, misi, tujuan/sasaran, dan program yang realistis dan mengantisipasi masa depan yang diinginkan dan dapat dicapai.

Penyusunan Rencana Bisnis dan Anggaran

Rencana Bisnis dan Anggaran (RBA) BLU memuat antara lain:

1. Kondisi kinerja BLU tahun berjalan;

2. Asumsi makro dan mikro;

3. Target kinerja (output yang terukur);

4. Analisis dan perkiraan biaya per output dan agregat;

5. Perkiraan harga dan anggaran;

6. Prognosa laporan keuangan.

Perencanaan dan penganggaran BLU pada prinsipnya tidak berbeda dengan perencanaan dan penganggaran pada kementerian/lembaga.

\section{Pengintegrasian Rencana Bisnis dan Anggaran dalam RKA-K/L}

RKA-K/L sebagai dokumen usulan anggaran (budget request) memuat sasaran terukur yang penyusunannya dilakukan secara berjenjang dari tingkat kantor/satuan kerja ke tingkat yang lebih tinggi (bottom-up) untuk melaksanakan penugasan dari menteri/pimpinan lembaga (top down). Dengan demikian dalam menyusun suatu Rencana Kerja dan Anggaran BLU harus menerapkan anggaran berbasis kinerja.

BLU sebagai satuan kerja merupakan bagian dari kementerian negara/lembaga. Oleh karena itu pengintegrasian RBA BLU ke dalam RKA-K/L dilakukan oleh kementerian negara/lembaga bersangkutan. Tata cara pengintegrasian RBA kedalam RKA-K/L berpedoman pada ketentuan dalam Peraturan Pemerintah Nomor 21 Tahun 2004 tentang Penyusunan Rencana Kerja dan Anggaran Kementerian Negara/Lembaga.

\section{Pelaksanaan Anggaran}

Pelaksanaan anggaran meliputi dokumen pelaksanaan anggaran, pengelolaan PNBP, dan revisi anggaran.

\section{Dokumen Pelaksanaan Anggaran}

Setelah RKA-KL dan Undang-undang APBN disahkan, pimpinan BLU menyesuaikan usulan Rencana Bisnis dan Anggaran (RBA) menjadi RBA Definitif. RBA definitif digunakan sebagai acuan dalam menyusun DIPA BLU untuk diajukan dan mendapat pengesahan Menteri Keuangan c.q. Direktur Jenderal Perbendaharaan.

DIPA BLU sekurang-kurangnya memuat:

1. seluruh pendapatan dan belanja BLU;

2. proyeksi arus kas;

3. jumlah dan kualitas barang dan/atau jasa yang dihasilkan;

4. rencana penarikan dana yang bersumber dari APBN;

5. besaran persentase ambang batas sebagaimana ditetapkan dalam RBA definitif.

Dalam hal DIPA BLU belum disahkan oleh Menteri Keuangan, BLU dapat melakukan pengeluaran paling tinggi sebesar angka dokumen pelaksanaan anggaran tahun lalu. 
DIPA BLU yang telah disahkan oleh Menteri Keuangan menjadi lampiran dari contractual performance agreement yang ditandatangani oleh menteri/pimpinan lembaga dengan pimpinan BLU yang bersangkutan dan sekaligus menjadi dasar penarikan dana.

\section{Pengelolaan PNBP}

Pengelolaan PNBP pada BLU mengikuti pedoman sebagai berikut.

1. Penggunaan PNBP

a. Pada BLU Penuh Satuan kerja berstatus BLU Penuh diberikan fleksibilitas pengelolaan keuangan, antara lain dapat langsung menggunakan seluruh PNBP dari pendapatan operasional dan nonopersaional, di luar dana yang yang bersumber dari APBN, sesuai RBA tanpa terlebih dahulu disetorkan ke Rekening Kas Negara. Apabila PNBP melebihi target yang ditetapkan dalam RBA tetapi masih dalam ambang batas fleksibilitas, kelebihan tersebut dapat digunakan langsung mendahului pengesahan revisi DIPA. Terhadap kelebihan PNBP yang melampaui ambang batas fleksibilitas, dapat digunakan dalam tahun berjalan setelah mendapat persetujuan Menteri Keuangan c.q. Dirjen Perbendaharaan atau menjadi saldo awal tahun berikutnya.

b. Pada BLU Bertahap Satker berstatus BLU Bertahap dapat menggunakan PNBP sebesar persentase yang telah ditetapkan. Sedangkan PNBP yang dapat digunakan langsung adalah sebesar persentase yang ditetapkan dalam Keputusan Menteri Keuangan tentang penetapan satker yang menerapkan PKBLU yang bersangkutan. Satker berstatus BLU Bertahap menyetor penerimaan PNBP yang tidak digunakan langsung ke Rekening Kas Negara secepatnya. PNBP yang telah disetor dapat dipergunakan kembali sebesar selisih antara PNBP yang dapat digunakan dengan PNBP yang telah digunakan langsung.

2. Pertanggungjawaban Pengunaan PNBP oleh BLU Satker BLU mempertanggungjawabkan pengggunaan PNBP secara langsung dengan menyampaikan SPM Pengesahan kepada KPPN setiap triwulan selambat-lambatnya tanggal 10 setelah akhir triwulan yang bersangkutan dengan dilampiri Surat Pernyataan Tanggung Jawab (SPTJ) yang ditandatangani oleh pimpinan BLU. Berdasarkan SPM pengesahan tersebut, KPPN menerbitkan SP2D sebagai pengesahan penggunaan dana PNBP. Pertanggungjawaban penggunaan dana PNBP selain yang digunakan langsung oleh satker yang berstatus BLU Bertahap menggunakan mekanisme pertanggungjawaban PNBP sebagaimana diatur dalam ketentuan perundangan yang berlaku (mengakomodasi perubahan Peraturan Dirjen Perbendaharaan Nomor PER-66/PB/2005).

\section{Revisi Anggaran}

DIPA BLU ataupun RBA Definitif apabila diperlukan dapat direvisi. Perubahan/revisi terhadap DIPA BLU atau RBA Definitif dapat dilakukan jika:

1. Terdapat perubahan/pergeseran program atau kegiatan BLU;

2. Terdapat penambahan atau pengurangan pagu anggaran yang berasal dari APBN;

3. Belanja BLU melampaui ambang batas fleksibilitas;

4. Belanja BLU sampai dengan ambang batas fleksibilitas.

Tata cara perubahan/revisi yang berhubungan dengan penganggaran dan perubahan program dan/atau kegiatan BLU berpedoman kepada Peraturan Pemerintah Nomor 21 Tahun 2004 atau Peraturan Menteri Keuangan (Nomor ?) tentang Mekanisme Revisi DIPA Kementerian Negara/Lembaga dan RBA serta pelaksanaan anggaran BLU. 
Perubahan/revisi sebagaimana dimaksud pada angka 4 dapat dilakukan setelah belanja dilaksanakan. Perubahan tersebut dapat dilaksanakan sebelum akhir tahun anggaran dalam bentuk pengesahan oleh Direktur Jenderal Perbendaharaan.

\section{Surplus dan Defisit BLU}

Surplus anggaran BLU adalah selisih lebih antara pendapatan dengan belanja BLU yang dihitung berdasarkan laporan keuangan operasional berbasis akrual pada suatu periode anggaran. Estimasi surplus dalam tahun anggaran berjalan diperhitungkan dalam RBA tahun anggaran berikut untuk disetujui penggunaannya.

Surplus anggaran BLU dapat digunakan dalam tahun anggaran berikutnya kecuali atas perintah Menteri Keuangan, disetorkan sebagian atau seluruhnya ke rekening kas umum negara dengan mempertimbangkan posisi likuiditas BLU.

Defisit anggaran BLU adalah selisih kurang antara pendapatan dengan belanja BLU yang dihitung berdasarkan laporan keuangan operasional berbasis akrual pada suatu periode anggaran.

Defisit anggaran BLU dapat diajukan pembiayaannya dalam tahun anggaran berikutnya kepada Menteri Keuangan melalui Menteri/Pimpinan Lembaga. Menteri Keuangan dapat mengajukan anggaran untuk menutup defisit pelaksanaan anggaran BLU dalam APBN tahun anggaran berikutnya.

\section{Pengelolaan Keuangan dan Barang}

Pengelolaan Keuangan dan Barang meliputi pengelolaan kas,

\section{Pengelolaan Kas}

Pengelolaan kas BLU dilakukan berdasarkan praktek bisnis yang sehat. Dalam melaksanakan pengelolaan kas, BLU menyelenggarakan hal-hal sebagai berikut :

1. Perencanaan penerimaan dan pengeluaran kas;

2. Pemungutan pendapatan atau tagihan;

3. Penyimpanan kas dan mengelola rekening bank;

4. Pembayaran;

5. Perolehan sumber dana untuk menutup defisit jangka pendek; dan

6. Pemanfaatan surplus kas jangka pendek untuk memperoleh pendapatan tambahan.

Pengelolaan kas BLU dapat dilakukan melalui:

1. Penarikan dana yang bersumber dari APBN dengan menerbitkan SPM;

2. Pembukaan Rekening Bank BLU oleh pimpinan BLU, sesuai dengan ketentuan yang berlaku kecuali dalam rangka cash management;

3. Investasi jangka pendek dalam rangka cash management (jika terjadi surplus kas) pada instrumen keuangan dengan resiko rendah.

\section{Pengelolaan Piutang}

Dalam pengelolaan keuangan, BLU dapat memberikan piutang terkait dengan kegiatannya, yang dikelola secara tertib, efisien, ekonomis, transparan, dan bertanggung jawab serta dapat memberikan nilai tambah, sesuai dengan praktek bisnis yang sehat dan ketentuan perundang-undangan yang berlaku. Piutang BLU dapat dihapus secara mutlak atau bersyarat oleh pejabat berwenang, yang nilainya ditetapkan secara berjenjang. Kewenangan penghapusan piutang secara berjenjang ditetapkan dengan Peraturan Menteri Keuangan dengan memperhatikan ketentuan peraturan perundang-undangan. 


\section{Pengelolaan Utang}

Dalam kegiatan operasional dengan pihak lain, BLU dapat memiliki utang yang dikelola secara tertib, efisien, ekonomis, transparan, dan bertanggung jawab, sesuai dengan praktek bisnis yang sehat. Pembayaran utang BLU pada prinsipnya menjadi tanggung jawab BLU. Pengelolaan utang harus sesuai dengan peruntukannya, utang jangka pendek ditujukan hanya untuk belanja operasional, sedangkan utang jangka panjang hanya untuk belanja modal. Hak tagih atas utang BLU kadaluarsa setelah lima tahun sejak utang tersebut jatuh tempo, kecuali ditetapkan lain oleh UU. Perikatan peminjaman/utang dilakukan sesuai dengan jenjang kewenangan yang diatur oleh Menteri Keuangan.

\section{Pengelolaan Investasi}

BLU tidak dapat melakukan investasi jangka panjang, kecuali atas persetujuan Menteri Keuangan. Investasi jangka panjang yang dimaksud antara lain adalah penyertaan modal, pemilikan obligasi untuk masa jangka panjang, atau investasi langsung (pendirian perusahaan). Jika BLU mendirikan/membeli badan usaha yang berbadan hukum, kepemilikan badan usaha tersebut ada pada Menteri Keuangan. Keuntungan yang diperoleh dari investasi jangka panjang merupakan pendapatan BLU.

\section{Akuntansi, Pelaporan dan Pertanggungjawaban}

Ruang lingkup ini mencakup akuntansi, pelaporan dan pertanggungjawaban

\section{Akuntansi}

BLU menyelenggarakan akuntansi sesuai dengan standar akuntansi keuangan yang diterbitkan oleh asosiasi profesi akuntan Indonesia, jika tidak ada standar akuntansi BLU yang bersangkutan dapat menerapkan standar akuntansi industri yang spesifik setelah mendapat persetujuan Menteri Keuangan.

BLU mengembangkan dan menerapkan sistem akuntansi dengan mengacu pada standar akuntansi yang berlaku sesuai dengan jenis layanannya dan ditetapkan oleh menteri/pimpinan lembaga.

\section{Pelaporan}

BLU menyampaikan laporan keuangan setiap triwulan kepada menteri/pimpinan lembaga berupa Laporan Realisasi Anggaran, Laporan Arus Kas, dan Catatan atas Laporan Keuangan dan Laporan keuangan yang lengkap (termasuk neraca dan ikhtisar laporan keuangan) pada setiap semester dan tahunan. Laporan-laporan tersebut disampaikan paling lambat satu bulan setelah periode pelaporan berakhir. Laporan keuangan unit-unit usaha yang diselenggarakan dikonsolidasikan oleh BLU dan menjadi lampiran laporan keuangan BLU.

Laporan keuangan BLU dikonsolidasikan dengan laporan keuangan kementerian/lembaga sesuai standar akuntansi pemerintahan dan diaudit oleh pemeriksa ekstern sesuai dengan ketentuan peraturan perundang-undangan.

\section{Pertanggungjawaban}

Menteri/pimpinan lembaga bertanggung jawab atas keberhasilan pencapaian sasaran program berupa hasil (political accountability), sedangkan pimpinan BLU bertanggung jawab atas keberhasilan pencapaian sasaran kegiatan berupa keluaran (operational accountability) dan terhadap kinerja BLU sesuai dengan tolok ukur yang ditetapkan dalam RBA.

\section{Pembinaan, Pemeriksaan}


Ruang lingkup meliputi pembinaan dan pemeriksaan

\section{Pembinaan}

Pembinaan teknis BLU dilakukan oleh menteri/pimpinan lembaga, sedangkan pembinaan di bidang keuangan dilakukan oleh Menteri Keuangan.

\section{Pemeriksaan}

Pemeriksaan intern BLU dilaksanakan oleh satuan pemeriksaan intern (SPI) yang merupakan unit kerja dan berkedudukan langsung di bawah pemimpin BLU, sedangkan pemeriksaan ekstern dilaksanakan oleh lembaga pemeriksa ekstern sesuai dengan ketentuan peraturan perundang-undangan.

\section{SIMPULAN}

Dalam dua dasa warsa terakhir, reformasi administrasi publik makin menguat di berbagai belahan dunia. Gelombang New Public Management (NPM) yang didasarkan atas pengalaman beberapa negara di Eropa, Amerika Serikat, dan negara maju lainnya secara bertahap diadopsi ke dalam tata kelola pemerintahan di berbagai negara, termasuk Indonesia. Transformasi manajemen pemerintahan dalam New Public Management mulai dari penataan kelembagaan, reformasi kepegawaian, dan reformasi pengelolaan keuangan Negara. Di dalam NPM tersebut pemerintah dianjurkan untuk meninggalkan paradigma lama seperti administrasi tradisional yang cenderung lebih mengedepankan sistem dan prosedur, birokratis yang gemuk dan tidak efisien, pemberian layanan yang lambat serta tidak efektif, digantikan dengan paradigma baru yang berorientasi pada kinerja dan hasil. Pemerintah dianjurkan untuk melepaskan diri dari birokrasi klasik, dengan mendorong organisasi dan pegawai agar lebih fleksibel, dan menetapkan tujuan, serta target organisasi secara lebih jelas sehingga memungkinkan pengukuran hasil.

Di lingkungan birokrasi pemerintahan, terdapat banyak satuan kerja yang berpotensi untuk dikelola secara lebih efisien dan efektif melalui pola BLU. Ada yang mendapatkan imbalan dari masyarakat dalam proporsi yang signifikan terkait dengan pelayanan yang diberikan, dan ada pula yang bergantung sebagian besar pada dana APBN/APBD. Satuan kerja yang memperoleh pendapatan dari layanannya dalam porsi signifikan, dapat diberikan keleluasaan dalam mengelola sumber daya untuk meningkatkan pelayanan yang diberikan. Peluang ini secara khusus disediakan bagi satuan kerja pemerintah yang melaksanakan tugas operasional pelayanan publik. Hal ini merupakan upaya peng-agenan aktivitas yang tidak harus dilakukan oleh lembaga birokrasi murni, tetapi oleh instansi pemerintah dengan pengelolaan ala bisnis, sehingga pemberian layanan kepada masyarakat menjadi lebih efisien dan efektif.

Dalam upaya meningkatkan layanan kepada publik, maka diperlukan pengaturan yang spesifik mengenai satuan kerja pemerintahan yang melakukan pelayanan kepada masyarakat yang saat ini bentuknya beraneka macam. Sesuai dengan pasal 1 butir (1). Undang-undang Nomor 23 Tahun 2005 tentang Pengelolaan Keuangan Badan Layanan Umum dinyatakan bahwa : "Badan Layanan Umum adalah instansi di lingkungan Pemerintah yang dibentuk untuk memberikan pelayanan kepada masyarakat berupa penyediaan barang dan/atau jasa yang dijual tanpa mengutamakan mencari keuntungan dan dalam melakukan kegiatannya didasarkan pada prinsip efisiensi dan produktivitas. Selanjutnya dalam ayat 2 dinyatakan, "Pola Pengelolaan Keuangan Badan Layanan Umum, yang selanjutnya disebut PPK-BLU, adalah pola pengelolaan keuangan yang memberikan fleksibilitas berupa keleluasaan untuk menerapkan praktek-praktek bisnis yang sehat untuk meningkatkan pelayanan kepada masyarakat dalam rangka memajukan kesejahteraan umum dan mencerdaskan kehidupan bangsa, sebagaimana diatur dalam Peraturan Pemerintah ini, 
sebagai pengecualian dari ketentuan pengelolaan keuangan negara pada umumnya. Suatu entitas pemerintah yang ingin mengajukan menjadi BLU harus memenuhi 3 persyaratan, yakni : persyaratan Substantif, persyaratan Teknis, dan persyaratan Administratif.

\section{Biodata Penulis :}

Indarto Waluyo, adalah pengajar di jurusan/prodi Akuntansi UNY, praktisi akuntansi, serta pemerhati masalah keuangan negara.

\section{DAFTAR PUSTAKA}

Direktorat Pembinaan PK BLU Direktorat Jenderal Perbendaharaan Departemen Keuangan RI, 2009, Implementasi Pengelolaan Keuangan Badan Layanan Umum, Surakarta.

Meidyawati. Analisis Implementasi Pola Pengelolaan Keuangan Badan Layanan Umum (PPK-BLU) Pada Rumah Sakit Stroke Nasional Bukit Tinggi. Diakses 10 Desember 2011 Jam 14.53.

Peraturan Pemerintah Republik Indonesia Nomor 23 Tahun 2005 tentang Pengelolaan Keuangan Badan Layanan Umum.

Peraturan Pemerintah Republik Indonesia Nomor 25 tahun 2005 tentang Standar Pelayanan Minimal.

Peraturan Menteri Keuangan Nomor 7/PMK.02/2006 tentang Persyaratan Administratif Dalam Rangka Pengusulan dan Penetapan Satuan Kerja Instansi Pemerintah untuk Menerapkan Pola Pengelolaan Keuangan Badan Layanan Umum (dicabut dengan Peraturan Menteri Keuangan Nomor 119/PMK.05/2007)

Peraturan Menteri Keuangan Nomor 8/PMK.02/2006 tentang Kewenangan Pengadaan Barang/Jasa pada Badan Layanan Umum;

Peraturan Menteri Keuangan Nomor 9/PMK.02/2006 tentang Pembentukan Dewan Pengawas pada Badan Layanan Umum (dicabut dengan Peraturan Menteri Keuangan Nomor 109/PMK.05/2007); 
Peraturan Menteri Keuangan Nomor 10/PMK.02/2006 tentang Pedoman Penetapan Remunerasi bagi Pejabat Pengelola, Dewan Pengawas, dan Pegawai Badan Layanan Umum sebagaimana telah diubah terakhir dengan Peraturan Menteri Keuangan Nomor 73/PMK.05/2007;

Peraturan Menteri Keuangan Nomor 66/PMK.02/2006 tentang Tata Cara Penyusunan, Pengajuan, Penetapan, dan Perubahan Rencana Bisnis dan Anggaran serta Dokumen Pelaksanaan Anggaran Badan Layanan Umum (dicabut dengan Peraturan Menteri Keuangan Nomor 44/PMK.05/2009);

Peraturan Menteri Keuangan Nomor 73/PMK.05/2007 tentang Perubahan atas Peraturan Menteri Keuangan Nomor 10/PMK.02/2006 Tentang Pedoman Penetapan Remunerasi bagi Pejabat Pengelola, Dewan Pengawas, dan Pegawai Badan Layanan Umum;

Peraturan Menteri Keuangan Nomor 109/PMK.05/2007 tentang Pembentukan Dewan Pengawas pada Badan Layanan Umum;

Peraturan Menteri Keuangan Nomor 119/PMK.05/2007 tentang Persyaratan Administratif dalam Rangka Pengusulan dan Penetapan Satuan Kerja Instansi Pemerintah untuk Menerapkan Pengelolaan Keuangan Badan Layanan Umum;

Peraturan Menteri Keuangan Nomor 76/PMK.05/2008 tentang Pedoman Akuntansi dan Pelaporan Keuangan BLU;

Peraturan Menteri Keuangan Nomor 99/PMK.05/2008 tentang Pedoman Pengelolaan Dana Bergulir Pada Kementrian Negara/Lembaga (diubah dengan Peraturan Menteri Keuangan Nomor 218/PMK.05/2009);

Peraturan Menteri Keuangan Nomor 197/PMK.05/2008 tentang Tata Cara Revisi DIPA untuk Satuan Kerja BLU Tahun Anggaran 2008;

Peraturan Menteri Keuangan Nomor 44/PMK.05/2009 tentang Rencana Bisnis dan Anggaran serta Pelaksanaan Anggaran Badan Layanan Umum (dicabut dengan Peraturan Menteri Keuangan Nomor 92/PMK.05/2011);

Peraturan Menteri Keuangan Nomor 77/PMK.05/2009 tentang Pengelolaan Pinjaman pada BLU;

Peraturan Menteri Keuangan Nomor 217/PMK.05/2009 tentang Pedoman Pemberian Bonus Atas Prestasi bagi Rumah Sakit Eks-Perjan yang Menerapkan Pengelolaan Keuangan Badan Layanan Umum;

Peraturan Menteri Keuangan Nomor 218/PMK.05/2009 tentang Perubahan atas Peraturan Menteri Keuangan Nomor 99/PMK.05/2008 tentang Pedoman Pengelolaan Dana Bergulir Pada Kementrian Negara/Lembaga;

Peraturan Menteri Keuangan Nomor 230/PMK.05/2009 tentang Penghapusan Piutang BLU;

Peraturan Menteri Keuangan Nomor 92/PMK.05/2011 tentang Rencana Bisnis dan Anggaran serta Pelaksanaan Anggaran Badan Layanan Umum; 
Peraturan Dirjen Perbendaharaan Nomor PER-30/PB/2011 tentang Mekanisme Pengesahan Pendapatan dan Belanja Satuan Kerja Badan Layanan Umum;

Peraturan Dirjen Perbendaharaan Nomor PER-55/PB/2011 tentang Tata Cara Revisi Rencana Bisnis dan Anggaran Definitif dan Revisi Daftar Isian Pelaksanaan Anggaran Badan Layanan Umum;

Supriyanto, Joko dan Suparjo, 2005, Badan Layanan Umum: Sebuah Pola Pemikiran Baru atas Unit Pelayanan Masyarakat, Diakses 10 Desember 2011 Jam 14.55, > http://syukriy.wordpress.com

Undang-Undang Nomor 15 Tahun 2004 tentang Pemeriksaan Pengelolaan dan Tanggung Jawab Keuangan Negara;

Undang-Undang Republik Indonesia Nomor 17 Tahun 2003 tentang Keuangan Negara.

Undang-Undang Republik Indonesia Nomor 1 Tahun 2004 tentang Perbendaharaan Negara.

Undang-Undang Republik Indonesia Nomor 25 Tahun 2009 tentang Pelayanan Publik.

Yuwana, Wirawan.2007.Badan Layanan Umum adalah Pengakuan Dosa. Diakses 10 Desember 2011 Jam 14.59, > http://masarie.wordpress.com

http://pkblu.perbendaharaan.go.id/

http://www.wikiapbn.org.id 